\title{
Comparison of Serum Myocardial Biomarkers Following Two Different Methods of Venoaortic Connection in Coronary Artery Bypass Grafting: A Randomized Clinical Trial
}

\author{
Gholamali Jelodar, ${ }^{1,}$ Khalil Zarrabi, ${ }^{2}$ Saeed Nazifi, ${ }^{3}$ and Azimeh Azimifar ${ }^{1}$ \\ ${ }^{1}$ Department of Physiology, Shiraz University, Shiraz, IR Iran \\ ${ }^{2}$ Department of Cardiothoracic Surgery, Shiraz University of Medical Sciences, Shiraz, IR Iran \\ ${ }^{3}$ Department of Clinical Pathology, Shiraz University, Shiraz, IR Iran \\ "Corresponding author: Dr. Gholamali Jelodar, Department of Physiology, Shiraz University, Shiraz, IR Iran. Tel: +98-7136138757, Fax: +98-7132286940, E-mail: \\ jelodar@shirazu.ac.ir \\ Received 2017 February 09; Revised 2017 April 05; Accepted 2017 June 04.
}

\begin{abstract}
Background: Myocardium will expose to excessive ischemia and reperfusion during post-cardiac surgery, hence the aim of this study was to investigate the cardioprotective effect of sequential partial aortic side biting technique for proximal veno-aortic anastomosis constructions in patients undergoing coronary artery bypass grafting (CABG).

Methods: In this randomized clinical trial study, 60 consecutive patients who were diagnosed to suffering from triple vessel coronary artery diseases were selected. CABG patients were assigned randomly into two groups; the first group received sooner and gradual myocardial reperfusion one-by-one top end venous anastomosis to the aorta (sequential aortic side biting technique) $(\mathrm{n}=$ 30) and the second group undergo proximal anastomoses constructed during a single period of aortic side biting (single aortic side biting technique) $(\mathrm{n}=30)$. The serum levels of myocardial damage biomarkers including creatine phosphokinase-MB (CPK-MB), Troponin I, glutathione peroxidase (GPX), superoxide dismutase (SOD), malondialdehyde (MDA) and catalase (CAT) were measured preoperatively, postoperatively and $24 \mathrm{~h}$ after operation. Independent $\mathrm{t}$ - tests was used to compare results between groups.

Results: The level of all myocardial biomarkers increased after the operation. Those in study group had significantly lower levels of troponin I $(\mathrm{P}<0.001)$, CPK-MB $(\mathrm{P}=0.001)$, GPX $(\mathrm{P}=0.007)$, SOD $(\mathrm{P}=0.005)$, and CAT $(\mathrm{P}=0.015), 24 \mathrm{~h}$ after the operation when compared to control group. Only the serum level of CPK-MB was significantly lower in study group after the operation $(\mathrm{P}=0.029)$ while the other markers were comparable.

Conclusions: Sequential partial occluding aortic side biting technique associated with less myocardial damage and ischemiareperfusion injury compared to conventional single method in patients undergoing elective coronary grafting.
\end{abstract}

Keywords: Myocardial Protection, Ischemia-Reperfusion, Coronary Bypass, Biomarkers

\section{Background}

Myocardial reperfusion injury is the phenomenon that describes myocardial damage occurring as a direct consequence of the restoration of blood flow to the ischemic tissue [1]. Following completing of surgery, cross-clamp of the aorta is removed, and the heart is immediately and totally reperfused with fully anticoagulated blood that is, saturated by a very high oxygen partial pressure. As a result, myocardium will expose to excessive ischemia and reperfusion during post-cardiac surgery [2]. Successful coronary artery bypass grafting (CABG) requires effective myocardial protection and preservation. Although several approaches for myocardial preservation during cardiopulmonary bypass (CPB) have been introduced till now, controversy still exists regarding the best method for this purpose [3-5]. The preferred way to protect myocardium is delivering of adequate cardioplegic solution to whole my- ocardium, and severe occlusion of the coronary arteries limit this delivery by the antegrade route [6]. Another important indicator of achieving favorable results of CABG is the surgical technique [7] or the direction of cardioplegia delivery [8]. Currently many cardiac surgeons construct the proximal veno-aortic anastomoses during a single period of aortic side biting. During this period, none of the venous grafts is filled with blood and thus the heart is exposed to relatively prolonged period of ischemia. There is increasing evidence to suggest that CABG with CPB can result in postsurgical complications in the form of reperfusion injury and myocardial cell death. At the end of ischemic period, cells will reversibly damage and at the time of reperfusion it will undergo irreversible damage. Indirect measurement of lipid peroxidation has demonstrated that reactive oxygen species (ROS) is produced during $C P B$. During the same time, the plasma level of cardiac troponin $\mathrm{T}$ is also increase significantly. ROS are directly cytotoxic 
to the myocardial cells and it is believed that myocardial reperfusion damage is due to both intracellular and extracellular production of ROS during cardiac surgery $[9,10]$. In this study, we hypothesized that constructing the proximal anastomoses one by one during several side biting periods would minimize the ischemic time and result in better myocardial protection. Thus this study was performed to compare level of some of biomarkers following two different methods of venoaortic connection in CABG.

In this study, we hypothesized that constructing the proximal anastomoses one by one during several side biting periods would minimize the ischemic time and result in better myocardial protection in patients undergoing coronary artery bypass grafting (CABG).

\section{Methods}

\subsection{Study Population}

This was a randomized, double blind, clinical trial study being performed during a 18-month period from January 2010 to July 2011, in cardiothoracic surgery department of Nemazee hospital, a tertiary healthcare center affiliated with Shiraz University of Medical Sciences. We selected 60 patients undergoing isolated CABG using CPB (Figure 1). All the patients were diagnosed to be suffering from triple vessel coronary artery disease with different occlusion degree of the left anterior descending (LAD) or other coronary arteries. All the patients were hemodynamically stable and none of them had history of neurological disease or psychiatric illness and none of them had clinical evidence of carotid and peripheral vascular disease. We excluded the patients with valvular heart diseases, renal failure (creatinine $>1.5 \mathrm{mg} / \mathrm{dL}$ ) or abnormal liver function (liver enzymes greater than twice the normal range) and any other serious life-threatening medical condition. We also excluded reoperations, combined procedures, poor left ventricular function (ejection fraction $<40 \%$ ), emergency CABG, aortic calcification determined preoperatively by transesophageal echocardiography and class III- IV congestive heart failure. In order to minimize the risk of cerebral embolization during the repetitive aortic manipulation, patients with atherosclerotic process of ascending aorta confirmed by transesophageal echocardiography and CT-angiography were not included. The study protocol was approved by Shiraz University institutional review board (IRB) and ethics committee and all the recruited patients provided their informed written consents.

\subsection{Intervention}

The included patients were randomly assigned to two study groups, according to their registration code (each containing 30 patients). The patients assigned to study group $(n=30)$ received sooner and gradual myocardial reperfusion by one-by-one proximal top end venous anastomosis to the aorta using multiple side biting of the ascending aorta (sequential aortic side biting technique). In this method after performing all the distal anastomoses, including to LAD the aortic cross clamp was removed and the proximal anastomoses of each venous graft were constructed one-by-one using multiple side biting of the ascending aorta (Figure 2 ). The patients in control group $(\mathrm{n}=30$ ) were operated according to the usual protocol in which during a single period of aortic cross-clamping distal anastomoses constructed and during re-warming, proximal anastomoses constructed with large side biting of the ascending aorta (single aortic side biting technique).

\subsection{Study Protocol}

All the included patients were visited by a single cardiothoracic surgeon (second author) during the previous day of the operation and a complete history and physical examinations as well as required paraclinical investigations were performed. Each patient received a random registration code generated by computer which was further used for randomization and follow-up. We performed transesophageal echocardiography and CT-angiography in all the eligible patients in order to rule out the aortic calcification and minimize the risk of cerebral embolism. In addition the surgeon examined the aorta during the operation in order to detect any calcification of the aortic wall in the site of puncture. All the patients were blinded regarding the method of operation. Before the operation, on induction of anesthesia, 5-mL venous blood sample was withdrawn from each patient. The anesthesia protocol was same in all the patients. Etomidate $(0.2-0.3 \mathrm{mg} / \mathrm{kg})$ or propofol ( $2 \mathrm{mg} / \mathrm{kg}$ ) was used to induce anesthesia. Fentanyl (15- $20 \mu \mathrm{g} / \mathrm{kg}$ ) was used as analgetic and pancuronium $(0.1 \mathrm{mg} / \mathrm{kg})$ or vecuronium (0.1-0.2 $\mathrm{mg} / \mathrm{kg})$ for neuromuscular blocker. Maintenance of anesthesia was achived with isoflurane. All the operations were performed by a single surgeon (second author) according to the aforementioned protocol (Figure 1). Another 5-mL venous blood sample was withdrawn exactly after the end of the operation. In the intensive care unit (ICU) a standardized protocol for weaning from assisted ventilation was followed.

\subsection{Outcome Assessment and Measurements}

We assessed the cardiac and neurologic outcome of the patients postoperatively both clinically and laboratory. The postoperative echocardiography was performed for all the patients in order to determine the ejection fraction and the left ventricular function as an indicator of cardiac 


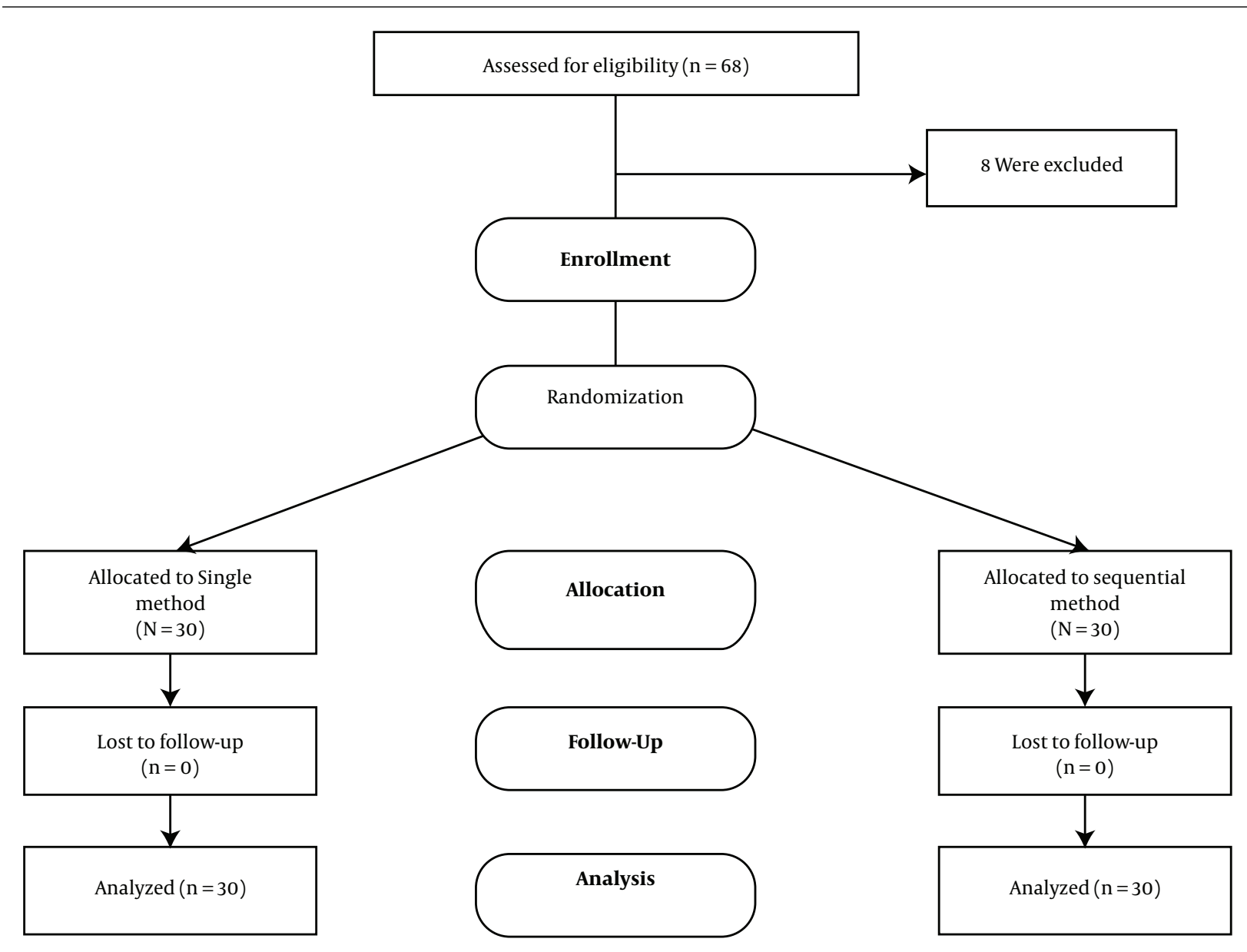

Figure 1. CONSORT Flow Diagram of the Study

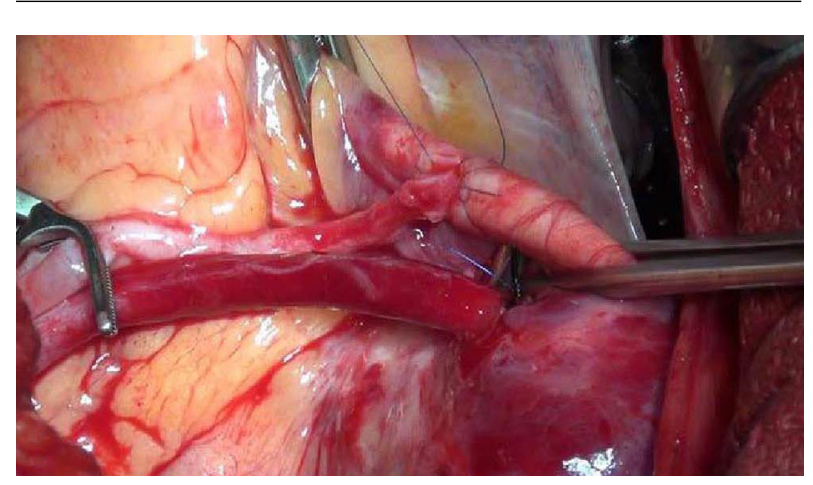

Figure 2. Performing the Proximal Venous Graft Anastomosis by Multiple Partial Occlusion of the Ascending Aorta (Side Biting Technique).

function after the operation. We also performed a complete neurological examination before and after the operation and any focal neurological sign after the operation was recorded and compared to preoperative findings. The specific serum marker of the cerebral injury which was protein S-100 before and after the operation was measured in order to determine the cerebral injury during the operation. The serum levels of protein S-100 was measured using a monoclonal two-site immunoradiometric assay (Sangtec $® 100$, AB Sangtec Medical, Bromma, Sweden) before and 24 hours after operation. Serum levels more than $0.2 \mathrm{mg} / \mathrm{L}$ were considered positive.

A venous blood sample was withdrawn from each patient before operation, exactly after the end of the operation and 24 hours after the operation to measure the myocardial enzymes and biomarkers. These markers included creatine phosphokinase-MB (CPK-MB), Troponin I, glutathione peroxidase (GPX), superoxide dismutase(SOD), malondialdehyde(MDA) and catalase(CAT). Troponin I and CPK-MB were measured by enzyme-linked immunosorbent assay (ELISA). Serum levels of CAT [11], SOD [12] and MDA [13] were measured according to the previ- 
ously described methods. GPX activity was measured using Cayman glutathione peroxidase estimate kit (Cayman Chemicals, Ann Arbor, MI) according to the manufacturer's instructions.

\subsection{Statistical Analysis}

In each group of study twenty-six patients were needed to have $90 \%$ power to detect significant differences between corresponding variables $(\mathrm{P}<0.05$, two-sided). To compensate for possible none valuable data, we have used 30 participants in each group. Data were analyzed by the statistical package for social science (SPSS version 15.0 SPSS, Chicago, IL). Comparing of results within groups was done by Paired t-tests; independent t-tests were used to compare results between the groups and to compare proportions the chi-square tests were used. Mann-Whitney test was applied to compare the parametric data without normal distribution between groups. Data are reported as means \pm $\mathrm{SD}$ and proportions where appropriate. A two-sided P value less than 0.05 was considered statistically significant.

\section{Results}

During the study we screened 68 patients out of whom 60 were found to be suitable for study. The patients were randomized into two study groups. Thus the final number of the patients in each study group was 30 . The baseline and operation feature of the patients are summarized in Table 1. No significant difference noticed between two study groups regarding the baseline characteristics. Those who underwent sequential partial occlusion method had significantly lower hospital stay compared to single occlusion method ( $7.3 \pm 2.4$ vs. $9.9 \pm 3.6 ; \mathrm{P}=0.031)$. None of the patients had preoperative focal neurological signs and the circulating level of protein S-100 was within normal range $(<0.2 \mathrm{mg} / \mathrm{L})$ in all the patients. The postoperative serum levels of myocardial biomarkers are summarized in Table 2. Serum levels of all myocardial biomarkers were comparable between two study groups before the operation. We found that serum level of troponin I was significantly lower in patients who underwent sequential partial occlusion, 24 hours after operation $(\mathrm{P}<0.001)$. In the same way, the serum levels of CPK-MB was significantly lower in study groups at the end of operation $(P=0.029)$ and 24 hours after operation $(\mathrm{P}=0.001)$. Patients in study group had also lower serum levels of GPX $(\mathrm{P}=0.007)$, SOD $(\mathrm{P}=$ $0.005)$ and $\mathrm{CAT}(\mathrm{P}=0.015)$ 24-hour after the operation. Two study groups were comparable regarding the serum levels of MDA both after the end of operation $(P=0.853)$ and 24 hours after $(\mathrm{P}=0.280)$. Serum levels of all myocardial biomarkers were comparable between two study groups after the end of operation except CPK-MB which was lower in study group (Table 2). None of the patients experiences side effects of the operation or neurological sequels. The neurological examinations in all the patients were normal and none of them had postoperative focal neurological signs. The circulating levels of protein S-100 was within normal range $(<0.2 \mathrm{mg} / \mathrm{L})$ in all the patients.

Table 1. Preoperative and Operation Characteristics of 60 Patients Undergoing $\mathrm{CABG}^{\mathrm{a}}$

\begin{tabular}{|c|c|c|c|}
\hline & $\begin{array}{l}\text { Study Group }(\mathbf{n}= \\
\mathbf{3 0})\end{array}$ & $\begin{array}{l}\text { Control Group (n } \\
\quad=\mathbf{3 0})\end{array}$ & PValue \\
\hline Age, $y$ & $64.17 \pm 8.92$ & $63.72 \pm 7.39$ & 0.128 \\
\hline Gender (M/F) & & & 0.562 \\
\hline Male, \% & $17(56.6)$ & $19(63.3)$ & \\
\hline Female, \% & $13(43.4)$ & $11(36.7)$ & \\
\hline \multicolumn{4}{|l|}{$\begin{array}{l}\text { Preoperative } \\
\text { Medications }\end{array}$} \\
\hline $\begin{array}{l}\text { Beta } \\
\text { blockers, \% }\end{array}$ & $23(76.6)$ & $19(63.3)$ & 0.097 \\
\hline $\begin{array}{l}\text { ACE } \\
\text { inhibitors, } \\
\%\end{array}$ & $26(86.6)$ & $25(83.3)$ & 0.566 \\
\hline $\begin{array}{l}\text { Frusemide, } \\
\%\end{array}$ & $13(43.3)$ & $14(46.6)$ & 0.856 \\
\hline $\begin{array}{l}\text { Ca-channel } \\
\text { blocker, \% }\end{array}$ & $3(10.0)$ & $4(13.3)$ & 0.574 \\
\hline Statins, \% & $22(73.3)$ & $26(86.6)$ & 0.075 \\
\hline $\begin{array}{l}\text { Ejection } \\
\text { fraction, \% }\end{array}$ & $48.79 \pm 4.75$ & $48.44 \pm 5.19$ & 0.316 \\
\hline $\begin{array}{l}\text { No. of } \\
\text { Grafts }\end{array}$ & $3.62 \pm 0.56$ & $3.58 \pm 0.50$ & 0.095 \\
\hline $\begin{array}{l}\text { LIMA grafts, } \\
\%\end{array}$ & $3.6 \pm 1.6$ & $3.4 \pm 1.2$ & 0.224 \\
\hline $\begin{array}{l}\text { CPB time, } \\
\text { min }\end{array}$ & $70.34 \pm 9.71$ & $69.06 \pm 7.86$ & 0.682 \\
\hline $\begin{array}{l}\text { Ischemic } \\
\text { time, min }\end{array}$ & $47.51 \pm 6.21$ & $47.20 \pm 5.53$ & 0.850 \\
\hline ICU stay, d & $2.1 \pm 0.81$ & $2.8 \pm 0.95$ & 0.062 \\
\hline $\begin{array}{l}\text { Hospital } \\
\text { stay, d }\end{array}$ & $7.3 \pm 2.4$ & $9.9 \pm 3.6$ & 0.031 \\
\hline
\end{tabular}

Abbreviations: CABG, coronary artery bypass surgery; CPB, cardiopulmonary bypass; ICU, intensive care unit; LIMA, left internal mammary artery.

${ }^{\mathrm{a}}$ Values are expressed as mean $\pm \mathrm{SD}$ or No. (\%).

Postoperative ejection fraction was not significantly different between two study groups ( $48.79 \pm 4.75$ vs. 48.44 $\pm 5.19 ; \mathrm{P}=0.428)$. We also found that the left ventricular function was comparable between groups both preoperatively $(\mathrm{P}=0.327)$ and postoperatively $(\mathrm{P}=0.088)$. 
Table 2. Serum Levels of Myocardial Biomarkers in 60 Patients Undergoing CABG with Two Different Methods

\begin{tabular}{|c|c|c|c|}
\hline & $\begin{array}{c}\text { Study Group }(\mathbf{n}= \\
\mathbf{3 0})\end{array}$ & $\begin{array}{c}\text { Control Group (n } \\
=\mathbf{3 0})\end{array}$ & P Value \\
\hline \multicolumn{4}{|l|}{ Troponin I, ng/mL } \\
\hline $\begin{array}{l}\text { Preopera- } \\
\text { tive }\end{array}$ & $0.0790 \pm 0.1$ & $0.1470 \pm 0.23$ & 0.853 \\
\hline $\begin{array}{l}\text { Postopera- } \\
\text { tive }\end{array}$ & $0.7510 \pm 0.7$ & $1.1830 \pm 1.08$ & 0.280 \\
\hline $\begin{array}{l}\text { 24-hour } \\
\text { after } \\
\text { operation }\end{array}$ & $0.140 \pm 0.06$ & $1.67 \pm 2.69$ & $<0.001$ \\
\hline \multicolumn{4}{|l|}{ CPK-MB, ng/mL } \\
\hline $\begin{array}{l}\text { Preopera- } \\
\text { tive }\end{array}$ & $1.48 \pm 2.8$ & $2.8 \pm 3.3$ & 0.123 \\
\hline $\begin{array}{l}\text { Postopera- } \\
\text { tive }\end{array}$ & $10.7 \pm 10.9$ & $16.8 \pm 10.4$ & 0.029 \\
\hline $\begin{array}{l}\text { 24-hour } \\
\text { after } \\
\text { operation }\end{array}$ & $4.9 \pm 2.4$ & $21.6 \pm 34.2$ & 0.001 \\
\hline \multicolumn{4}{|l|}{ GPX, U/gHb } \\
\hline $\begin{array}{l}\text { Preopera- } \\
\text { tive }\end{array}$ & $36.3 \pm 1.5$ & $36.7 \pm 1.2$ & 0.529 \\
\hline $\begin{array}{l}\text { Postopera- } \\
\text { tive }\end{array}$ & $31.1 \pm 0.5$ & $31.6 \pm 0.7$ & 0.075 \\
\hline $\begin{array}{l}\text { 24-hour } \\
\text { after } \\
\text { operation }\end{array}$ & $22.2 \pm 1.5$ & $24.2 \pm 1.7$ & 0.007 \\
\hline \multicolumn{4}{|l|}{ SOD, U/gHb } \\
\hline $\begin{array}{l}\text { Preopera- } \\
\text { tive }\end{array}$ & $1334.6 \pm 29.8$ & $1347.1 \pm 13.7$ & 0.579 \\
\hline $\begin{array}{l}\text { Postopera- } \\
\text { tive }\end{array}$ & $1306.1 \pm 4.9$ & $1308.9 \pm 6.9$ & 0.393 \\
\hline $\begin{array}{l}\text { 24-hour } \\
\text { after } \\
\text { operation }\end{array}$ & $1103.1 \pm 11.2$ & $1151.2 \pm 64.1$ & 0.005 \\
\hline \multicolumn{4}{|l|}{ MDA, U/gHb } \\
\hline $\begin{array}{l}\text { Preopera- } \\
\text { tive }\end{array}$ & $1.24 \pm 0.64$ & $1.25 \pm 0.07$ & 0.579 \\
\hline $\begin{array}{l}\text { Postopera- } \\
\text { tive }\end{array}$ & $1.49 \pm 0.73$ & $1.48 \pm 0.06$ & 0.853 \\
\hline $\begin{array}{l}\text { 24-hour } \\
\text { after } \\
\text { operation }\end{array}$ & $1.76 \pm 0.16$ & $1.86 \pm 0.07$ & 0.280 \\
\hline \multicolumn{4}{|l|}{ CAT, U/gHb } \\
\hline $\begin{array}{l}\text { Preopera- } \\
\text { tive }\end{array}$ & $0.85 \pm 0.009$ & $0.85 \pm 0.006$ & 0.971 \\
\hline $\begin{array}{l}\text { Postopera- } \\
\text { tive }\end{array}$ & $0.78 \pm 0.008$ & $0.78 \pm 0.005$ & 0.436 \\
\hline $\begin{array}{l}\text { 24-hour } \\
\text { after } \\
\text { operation }\end{array}$ & $0.64 \pm 0.003$ & $0.62 \pm 0.005$ & 0.015 \\
\hline
\end{tabular}

Abbreviations: CAT, catalase; CPK-MB, creatine phosphokinase-MB; GPX, glutathione peroxidase; MDA, malondialdehyde; SOD, superoxide dismutase.

\section{Discussion}

The results of this randomized clinical trial indicate that sequential partial occluding aortic side biting technique is associated less myocardial damage and ischemiareperfusion injury compared to single method in patients undergoing elective coronary grafting. In other words, sequential partial occlusion of the aorta during the coronary grafting damages the myocardium less when compared to single side biting technique. In addition none of the patients developed cerebrovascular events, indicating that both methods are safe for brain preservation.

Several interdependent mechanisms which are involved in the formation of ROS may cause reperfusion injury. The produced ROS during oxidative stress will result in proteins oxidation, peroxidation of lipids, and nitric oxide (NO) inactivation, leading to endothelial damage and micro-vascular dysfunction $[14,15]$. This may delay post $\mathrm{CABG}$ recovery of cardiac function.

Cellular mechanisms that promote reperfusion injury are incompletely understood $[16,17]$. Ischemia-reperfusion injury induces several histopathological changes and a cascade leading to tissue injury. These events and changes include oxygen radical formation, neutrophil infiltration along with release of inflammatory cytokines. These lead to activation of coagulation cascade and kallikrein system accompanied by increased vascular and cell permeability [18].

During CABG surgery myocardial cells are susceptible to ischemia due to various factors such as coronary artery disease or embolization, instable perioperative hemodynamic, improper protection during cardiopulmonary bypass, or technical complications. Although prolonged ischemia condition alone can structurally and biochemically damage the integrity of the myocardial cells, limited oxygen deprivation ( $<20$ minutes) is usually correlated with transient depressed myocardial contractility [19]. Paradoxically, following sustained myocardial ischemia (> 45 minutes) restoration of blood flow will results in myocardial ischemic reperfusion (I-R) injury, wherein after reperfusion the tissue damage is greater than that produced by ischemia alone [20].

Evidence regarding association of myocardial injury following reperfusion of ischemia was made in 1960 by Jennings and colleagues [21]. Their report was according to experiments on canine hearts following coronary ligation in which reperfusion accelerated the development of necrosis [16]. Several pathophysiologic processes contribute to myocardial I-R injury during perioperative cardiac dysfunction and related morbidity. Therefore, a great attempt has been made to introduce new surgical methods and pharmacologic agents that may eliminate or decline 
subsequent pathophysiologic side effects of proinflammatory mediators [20].

The preferred technique to protect myocardium is delivering of adequate cardioplegic solution to whole myocardium, and severe occlusion of the coronary arteries reduces this delivery by the antegrade route [6]. To protection myocardium during coronary bypass operations, retrograde administration of the cardioplegia via coronary sinus can be a desire technique [6]. However, it have been shown in experimental studies that there is superior myocardial protection of the left ventricle with the use of retrograde cardioplegia, even with the patent coronary arteries, but in the right ventricle there is less favorable protection [22].

In our method we try to reduce the magnitude of myocardial damage by reperfusing the myocardium sooner and gradually by means of one-by-one proximal top end venous anastomosis to the aorta using multiple partial occlusion of the ascending aorta.

Elevation of postoperative CPK-MB and troponin I results from myocardial acidosis and damage during operation. The strong correlation between troponin I, adverse events, and cost indicates the injury incurred is clinically and economically relevant [23]. In clinical studies direct relationship between level of myocardial acidosis during intra-operation and short- and long-term postoperative outcomes have been demonstrated [19-21].

Our results show that in the study group serum levels of CPK-MB, troponin I, GPX, CAT and SOD was significantly lower compared to control group 24-hour after the operation. These markers are all considered to be myocardial damage biomarkers and their increase is suggestive of myocardial ischemic damage [14, 24-27].

Increased production of free radicals such as superoxide anions and hydroxyl radicals immediately after CABG may be due to increase activity of GPX and SOD in patients [22].

Formation of ROS can directly damage cellular membranes through lipid peroxidation and their role in myocardial I/R injury have been intensively studied $[28,29]$. In the our study, the postoperative activity of GPX, CAT and SOD were less in the study group compared to control group suggesting that the sequential aortic side biting surgical technique cause less oxidative stress during surgery. A postoperative GPX activity was proposed to be as valuable index to evaluate oxidative stress induced during reperfusion [24]. The main limitation of our study is the fact that atherosclerosis of the ascending aorta may be as one of the most important sources of emboli production after CABG. Cannulation and clamping of atherosclerotic aorta can result in intraoperative embolization into the cerebral circulation, causing persistent cognitive deficit or post-operative stroke [30, 31]. Diagnosis of atherosclerosis of ascending aorta is critical to avoid aortic clamping in such patients, as intraoperative maneuvers may reduce the risk of preoperative stroke [32]. Epiaortic ultrasound is a useful method to detect the atherosclerosis grade of ascending aorta [30]. This facility was not accessible in our study and we relied on pre-op transesophgeal echocardiographs and intraoperative findings and the patients with atherosclerotic process in ascending aorta excluded from the study and we had no neurologic complication in our patients [30].

In conclusion, sequential partial occluding aortic side biting technique is associated with less oxidative stress, myocardial damage and ischemia-reperfusion injury compared to single method in patients undergoing elective coronary grafting. Thus this method could be recommended for myocardial preservation during cardiopulmonary bypass and coronary grafting.

\section{Footnotes}

Conflict of Interest: There isn't any conflict of interest to be declared regarding the manuscript. This work was conducted as MSc thesis of Mrs. Azimifar under supervision of Dr. Jelodar, cardiovascular surgery was done by Dr. Zarrabi, and Para clinical parameters was done and described by assistance of Dr. Nazifi.

Funding/Support: This work was financially supported by authors.

\section{References}

1. Prasad A. Post-conditioning for cardioprotection during reperfusion therapy: too good to be true? JACC Cardiovasc Interv. 2010;3(1):56-7. doi:10.1016/j.jcin.2009.11.002. [PubMed: 20129569].

2. Turer AT, Hill JA. Pathogenesis of myocardial ischemia-reperfusion injury and rationale for therapy. Am J Cardiol. 2010;106(3):360-8. doi: 10.1016/j.amjcard.2010.03.032. [PubMed: 20643246].

3. Fan Y, Zhang AM, Xiao YB, Weng YG, Hetzer R. Warm versus cold cardioplegia for heart surgery: a meta-analysis. Eur J Cardiothorac Surg. 2010;37(4):912-9. doi: 10.1016/j.ejcts.2009.09.030. [PubMed: 19850490].

4. Thielmann M, Kottenberg E, Kleinbongard P, Wendt D, Gedik N, Pasa $\mathrm{S}$, et al. Cardioprotective and prognostic effects of remote ischaemic preconditioning in patients undergoing coronary artery bypass surgery: a single-centre randomised, double-blind, controlled trial. Lancet. 2013;382(9892):597-604. doi: 10.1016/S0140-6736(13)61450-6. [PubMed: 23953384].

5. Kinoshita T, Asai T. Preservation of myocardium during coronary artery bypass surgery. Curr Cardiol Rep. 2012;14(4):418-23. doi: 10.1007/s11886-012-0271-0. [PubMed: 22528557].

6. Sanjay OP, Srikrishna SV, Prashanth P, Kajrekar P, Vincent V. Antegrade versus antegrade with retrograde delivery of cardioplegic solution in myocardial revascularisation. A clinical study in patients with triple vessel coronary artery disease. Ann Card Anaesth. 2003;6(2):1438. [PubMed: 17827576]. 
7. Hausenloy DJ, Boston-Griffiths E, Yellon DM. Cardioprotection during cardiac surgery. Cardiovasc Res. 2012;94(2):253-65. doi 10.1093/cvr/cvs131. [PubMed: 22440888].

8. Abu-Omar Y, Balacumaraswami L, Pigott DW, Matthews PM, Taggart DP. Solid and gaseous cerebral microembolization during off-pump, on-pump, and open cardiac surgery procedures. J Thorac Cardiovasc Surg. 2004;127(6):1759-65. doi: 10.1016/j.jtcvs.2003.09.048. [PubMed: 15173734].

9. Kloner RA, Przyklenk K, Whittaker P. Deleterious effects of oxygen radicals in ischemia/reperfusion. Resolved and unresolved issues. Circulation. 1989;80(5):1115-27. [PubMed: 2553296].

10. Opie LH. Reperfusion injury and its pharmacologic modification. Circulation. 1989;80(4):1049-62. [PubMed: 2571429].

11. Clairborne A. In: Handbook of methods for oxygen radical research. Greenwald RA, editor. Boca Raton: CRC Press; 1985. p. 283.Catalase activity.

12. Mohanty I, Arya DS, Dinda A, Talwar KK, Joshi S, Gupta SK. Mechanisms of cardioprotective effect of Withania somnifera in experimentally induced myocardial infarction. Basic Clin Pharmacol Toxicol. 2004;94(4):184-90. doi: 10.1111/j.1742-7843.2004.pto940405.x. [PubMed: 15078343].

13. Ohkawa H, Ohishi N, Yagi K. Assay for lipid peroxides in animal tissues by thiobarbituric acid reaction. Anal Biochem. 1979;95(2):351-8. [PubMed: 36810].

14. Blankenberg S, Rupprecht HJ, Bickel C, Torzewski M, Hafner G, Tiret $\mathrm{L}$, et al. Glutathione peroxidase 1 activity and cardiovascular events in patients with coronary artery disease. NEnglJMed. 2003;349(17):160513. doi: 10.1056/NEJMoa030535. [PubMed:14573732].

15. Gerritsen WB, van Boven WJ, Boss DS, Haas FJ, van Dongen EP, Aarts LP. Malondialdehyde in plasma, a biomarker of global oxidative stress during mini-CABG compared to on- and off-pump CABG surgery: a pilot study. Interact Cardiovasc Thorac Surg. 2006;5(1):27-31. doi: 10.1510/icvts.2005.116061. [PubMed: 17670506].

16. Yetgin T, Manintveld OC, Boersma E, Kappetein AP, van Geuns RJ Zijlstra F, et al. Remote ischemic conditioning in percutaneous coronary intervention and coronary artery bypass grafting. Circ J. 2012;76(10):2392-404. [PubMed: 22785338].

17. Prabhu A, Sujatha DI, Ninan B, Vijayalakshmi MA. Neutrophil gelatinase associated lipocalin as a biomarker for acute kidney injury in patients undergoing coronary artery bypass grafting with cardiopulmonary bypass. Ann Vasc Surg. 2010;24(4):525-31. doi: 10.1016/j.avsg.2010.01.001. [PubMed: 20363104]

18. Hausenloy DJ, Yellon DM. Remote ischaemic preconditioning underlying mechanisms and clinical application. Cardiovasc Res. 2008;79(3):377-86. doi: 10.1093/cvr/cvn114. [PubMed: 18456674].

19. Park JL, Lucchesi BR. Mechanisms of myocardial reperfusion injury. Ann Thorac Surg. 1999;68(5):1905-12. [PubMed: 10585102].

20. Shernan SK. Perioperative myocardial ischemia reperfusion injury.
Anesthesiol Clin North America. 2003;21(3):465-85. [PubMed: 14562561].

21. Jennings RB, Sommers HM, Smyth GA, Flack HA, Linn H. Myocardial necrosis induced by temporary occlusion of a coronary artery in the dog. Arch Pathol. 1960;70:68-78. [PubMed:14407094].

22. Partington MT, Acar C, Buckberg GD, Julia P, Kofsky ER, Bugyi HI. Studies of retrograde cardioplegia. I. Capillary blood flow distribution to myocardium supplied by open and occluded arteries.J Thorac Cardiovasc Surg. 1989;97(4):605-12. [PubMed: 2927164].

23. Rousou LJ, Crittenden MD, Taylor KB, Healey NA, Gibson S, Thatte HS, et al. Troponin I after cardiac surgery and its implications on myocardial protection, outcomes, and cost.Am JSurg. 2008;196(5):703-9. doi: 10.1016/j.amjsurg.2008.07.002. [PubMed:18789416].

24. Chandrasena LG, Peiris H, Waikar HD. Biochemical changes associated with reperfusion after off-pump and on-pump coronary artery bypass graft surgery. Ann Clin Lab Sci. 2009;39(4):372-7. [PubMed: 19880765].

25. Espinola-Klein C, Rupprecht HJ, Bickel C, Schnabel R, Genth-Zotz S, Torzewski M, et al. Glutathione peroxidase-1 activity, atherosclerotic burden, and cardiovascular prognosis. Am J Cardiol. 2007;99(6):80812. doi: 10.1016/j.amjcard.2006.10.041. [PubMed: 17350371].

26. Poling J, Rees W, Klaus S, Bahlmann L, Hubner N, Mantovani $\mathrm{V}$, et al. Myocardial metabolic monitoring with the microdialysis technique during and after open heart surgery. Acta Anaesthesiol Scand. 2007;51(3):341-6. doi:10.1111/j.1399-6576.2006.01241.x. [PubMed: 17257174].

27. Luyten CR, van Overveld FJ, De Backer LA, Sadowska AM, Rodrigus IE, De Hert SG, et al. Antioxidant defence during cardiopulmonary bypass surgery. Eur J Cardiothorac Surg. 2005;27(4):611-6. doi: 10.1016/j.ejcts.2004.12.013. [PubMed: 15784359].

28. Zhou T, Chuang CC, Zuo L. Molecular Characterization of Reactive Oxygen Species in Myocardial Ischemia-Reperfusion Injury. Biomed Res Int. 2015;2015:864946. doi: 10.1155/2015/864946. [PubMed: 26509170].

29. Jiban D, L KN. A review on pathophysiology of ischemic-reperfusion injury of heart and ameliorating role of flavonoids and polyphenols. J Med Plants Res. 2014;8(16):607-14. doi: 10.5897/jmpr2014.5360.

30. El Zayat H, Puskas JD, Hwang S, Thourani VH, Lattouf OM, Kilgo P, et al. Avoiding the clamp during off-pump coronary artery bypass reduces cerebral embolic events: results of a prospective randomized trial. Interact Cardiovasc Thorac Surg. 2012;14(1):12-6. doi:10.1093/icvts/ivr004. [PubMed: 22108921].

31. Mark DB, Newman MF. Protecting the brain in coronary artery bypass graft surgery. JAMA. 2002;287(11):1448-50. [PubMed: 11903033].

32. Hilker M, Arlt M, Keyser A, Schopka S, Klose A, Diez C, et al. Minimizing the risk of perioperative stroke by clampless off-pump bypass surgery: a retrospective observational analysis. J Cardiothorac Surg. 2010;5:14. doi: 10.1186/1749-8090-5-14. [PubMed: 20334704]. 